$1 \mathrm{BS}=$

Online ISSN: 2582-3574

Print ISSN: 2582-4406

\section{SMART MOVES JOURNAL MELLH

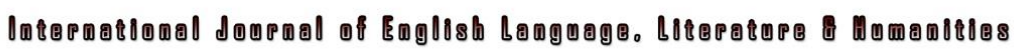

Volume 7, Issue 12, December 2019

DOI: https://doi.org/10.24113/ijellh.v7i12.10211

\title{
Motivational EFL Classroom Strategies and Effective Teaching
}

Mahbubul Alam

Lecturer, Department of English

Faculty of Arts and Humanities

Jazan University, Saudi Arabia

mahbub.ju80@gmail.com

Nawshan Ara Rima

M.A. in English

Islamic University, Kushtia

Bangladesh

Abstract

Nowadays, eminent linguists and teachers training specialists are visiting different corners of the world and prescribing different methods on how to teach English as a Foreign Language 
effectively. Although their endeavours bring success, sometimes it doesn't work everywhere well since the urge of learning English depends on the socio-economic and cultural background of a particular country or a specific class society. Consequently, the techniques and the methodologies that work well in a in an advanced country may not suit in a developing country. The same thing may happen in among the economically higher class students and the lower class students even in a developing country. As for example, the lower class students are pre-occupied with the idea that without a good knowledge in English they won't get a good job and thus, they are motivated enough by their guardians, by their teachers, and by the socio-economic realities from the very beginning of their life and pick up English very quickly. On the other hand, the higher class students don't think English is a must to get a secured job. Rather, they foster the idea in their mind that even without a good knowledge in English they are able to manage it and lead their life comfortably. Keeping all these facts in mind, we have tried to focus on how to motivate these higher class students and turn their mind to learn English through different classroom activities as a means of effective teaching. Based on the demands of the students, what they really expect from an English teacher and the experience of a teacher in the class, this article attempts to find out a teacher's own strategies along with some established ones which they can apply in the class to make it interactive and effective.

Key Words: Motivation, EFL, Social Class, Strategies, Teaching.

Introduction:

English is taught and learnt as a foreign language in Bangladesh. Here the lower class students try their level best to pick up English despite the harsh realities of life. They think that only a good command in English can secure them a good job apart from other boble causes. 
Therefore, these students are self motivated to learn English. On the other hand, the students of the higher class, in most cases, don't feel that much interest to learn English. Although they speak English, may be as part of their fashion, they don't have that much command in English in terms of effective writing, reading and listening. They think even without learning English, they can lead their life very comfortably as they are getting everything needed for life quite easily which leads them to the utmost laziness in terms of learning English. And it confines the students' efforts, endevour, the mind as well. They can't broaden their mind. Because of all these factors, the students here can't fix their goal and measure their bright future in the field of English. In such a state, a good teacher can play an important role to apply different strategies to motivate these students for effective teaching in many ways as if these students feel interest to learn English effectively.

\section{Effective Teaching:}

Effective teaching means the methods of teaching which guarantee maximal learning. It also implies the minimal waste of time and effort on the part of both the students and teachers that lead to the best results. Effective teaching is often accompanied by not only with good learning, but also with happy learning, too. The students can benefit themselves from effective teaching and learning strategies inside and outside the classroom. Identifying effective teaching strategies is, therefore, the main challenge of a good teacher. A good teacher always assesses the effectiveness of the current teaching strategies and consider the innovative ways to improve his teaching style to match the students learning style. Above all, effective teaching involves motivation through different classroom strategies that makes learning a pleasant experience to the students. 
Motivation:

The word "motivation" is typically defined as the forces that account for the arousal, selection, direction, and continuation of behavior. As Alexenoamen (2009-11:54) notes, motivation can be defined as a concept used to describe the factors within an individual which arouse, maintain, and channel behavior towards a goal. Another way to say this is that motivation is goal- directed behavior.

This motivation has long been a major problem for most of the teachers of English as a Foreign Language. The main reason is that most of the students here have low motivation to learn English. If the students are not motivated, it would be really difficult for the teacher to teach them English. That is why motivation plays an important role for effective teaching. As Dornyei (2001:116) notes, "teacher skills in motivating learners should be seen as central to teaching effectiveness." Motivation itself can be a good strategy for effective teaching. A good teacher, therefore, tries to understand the motivation level of the students and accordingly can take the following steps to motivate them for good learning.

Importance of English:

If the students are not aware of the importance of learning English, they will not get interest to learn it. Therefore, a teacher can tell them in the class how they will be benifited if they learn English. For this purpose, a teacher can place the following things before the students:

1. It is an international language.

2. It is needed to take higher education in almost all the fields.

3. It is needed for travelling abroad. 
4. It is needed to run an international business.

5. It is a must to get a good job.

Teacher's own achievement:

Some students in the class do not like to live only in hope and imagination. Rather, they want to see the benefit of learning English practically. For these students a teacher himself can be a real example. The teacher can tell them what he has achieved as an English teacher. Here, we can talk about the achievements of an English teacher in the following way:

1. The name of the teacher is $\mathrm{X}$ for example.

2. Immediately after the completion of his Masters in English, he joined the China World Best Group of Companies as a communication officer.

3. Then, he worked in the ACCESS program patronised by The USA State Department in Bangladesh as a language instructor.

4. He also worked in a University as a lecturer in the Department of English.

5. Now, he is working in the Department of English in a foreign University.

6. In all these places he has got high salary.

7. He has got high social status.

8. All the people love and respect him.

After getting such of his achievements, what we notice in the class is they feel extremely high about him. Even they can not help praising him saying "very good", "excellent", "you are a 
good teacher" etc. Now if he ask them some questions like Is English necessary?, Do you want to learn English?, Do you want to be a teacher like him? All of them repply "Yes". In the same way, a teacher can tell the acheivements of some other teachers. Certainly the students will foster the idea to be a person like their teacher. Besides these, a teacher can tell the story of some good students of their institution who have become successful in their life after learning English. Thus, a teacher can motivate his students to learn English.

Teacher's personality:

The learning community consists of both students and teachers. The learners have to pass a lot of time in direct contact with the teachers. Therefore, they get a chance to form some ideas about the teachers. A teacher's personality can affect these ideas of the students. A good teacher can, therefore, influence his students with his good personality:

1. The teacher must maintain a good appearance because he will be looked at as an example and surveyed from head to foot by scores of students' examining eyes.

2. He should be fair to all his students.

3. He has to treat them equally without any prejudice for or against any of them.

4. He should be kind to his students.

5. A teacher should talk to his students both inside and outside the classroom. If he meets them in the hall, in the caffeteria, or at the grocery store, he should ask them how they are.

Besides the personality, a teacher should take care about the following things which also help to motivate the students (Mohammad Ali Alkhuly1980:17): 
1. The teacher's voice must be clear and loud enough to be easily heard by all the students in the classroom.

2. The teacher should prepare his lesson very well in respect of what and how he is going to teach.

3. He should master his subject matter and know more than his students and what the text book offers.

Use of incentives:

The use of incentives is based on the principle that learning occurs more effectively when the students experience feelings of satisfaction as Barbara Gross Davis notes. Incentives include privileges and receiving praise from the instructor. The instructor determines an incentive that is likely to motivate an individual at a particular time. In a general learning situation, self motivation without rewards will not succeed. Therefore, a teaacher should congratulate his students if he finds them in the local newspaper or in the journal of their institution. He can also appreciate their kindness if the students do something nice. Sometimes, after checking their homework if he put his signature on their notebook, the students become very happy. All these pretty but important activities of a teacher let the students know that the teacher really do care about them and they are satisfied with the teacher indeed which is very necessary for effective teaching.

However, motivational strategies can not work in a vacuum, nor are they set in stone, observes Dimitrios Thanasoulas. There are certain preconditions to be met before any attempts to generate motivation can be effective. Some of these conditions are the following: 
1. Appropriate teacher behaviour and good teacher- student rapport: Whatever is done by a teacher has a motivational, formative, influence on students. In other words, teacher behaviour is a powerful motivational tool( Dornyei, 2001:120). If a teacher behaves well with the students, he can attract the students and engage them in tasks. For Alison(1993), a key element is to establish a mutual trust and respect with the learners, by means of talking with them at a personal level. This mutual trust could lead to enthusiasm which make the students take from the teacher about how to behave.

2. A pleasant and supportive classroom atmosphere: A tense classroom climate can undermine learning and demotivate learners (Macintyre,1999). On the other hand, learner motivation will reach its peak in a safe classroom climate in which students can express their opinions and feel that they do not run the risks of being ridiculed. A good teacher can organise and manage the classroom as an effective learning environment. Furthermore, because anxious or alieneted students are unlikely to develop motivation to learn it is important that learning occur within a relaxed and supportive atmosphere (Good and Brophy, 1994:215).

A good teacher also takes care about the appropriate use of the air-conditioners, windows, fans, lights and cleanliness of the classroom. Moreover, to maintain a pleasant classroom atmosphere Rosie Tanner and Catherine Green suggest the following things:

1. Teaching space: Teachers have their own teaching space in a classroom. This is the area where they prefer to sit or stand in a classroom. A teacher has to select his space in such a way that he can move to every student. At the same time he has to stand in 
front of the class when he wants to ask question or explain something.

2. Eye contact: While teaching, a teacher should not concentrate on some good students who actively participate in the class. Rather, he should direct his eyes to all the students. In the full class phases, if the teacher does not have eye contact with the students, then attention is likely to drop. So, eye contact gives the students a feeling of satisfaction and importance.

3. Body language: In EFL class, a teacher should be well versed in using body language to communicate his class. A teacher can use his fingers, hands, face and eyes to make them understand many things.

The first day of class:

It can play an important role to motivate the students. If a teacher can successfully deal the first class, he will be able to control the students throughout the whole semester. It is not an easy task. Because, students come from all walks of life in a class. They are from different socioeconomic and cultural backgrounds. They have their own likings and dislikings. Even their level of understanding is also different. In such a state, Rosie Tanner and Catherine Green suggest a teacher to take the following actions to make the students form a good idea about him:

1. Establish a particular classroom atmosphere: co-operative and respectful.

2. Establish a code of classroom conduct.

3. Learners introduce themselves, or each other, or learn something about each other.

4. Introduce yourself. 
5. Learn about learners' expectations.

6. Present the course: point out important information about course content, ways of working, and assessment.

7. Pre-test learners to assess their proficiency level.

8. Teach a typical lesson and give an introduction for the second lesson.

By doing so, a teacher can make the students believe that he is well qualified and interesting. If they are convinced that he really likes and loves them, a teacher can make some rules to be abided by in the class such as:

1. Please be on time for every class and I shall do the same.

2. Home work must be handed in on time.

3. When I speak, please keep silent.

4. If you are late, take permission from the teacher to enter into the class.

Moreover, a teacher can invite the students to add some other rules that they would like to be kept. Learners discuss their ideas in groups or give individual suggestions. A poster is made and mounted of the rules that the class has negotiated, so that everyone can see the rules.

A teacher is also suggested to use some ice-breaking techniques to reduce tension and anxiety. He can be creative and design his own variations. He can make different experiments and try different approaches, and above all, have fun and start that most important first day of class on the right foot. 
Use of games:

Language learning is a hard task which can sometimes be frustrating. Constant effort is required to understand, produce and manipulate the target language, says Aydan Ersoz. Well chosen games are invaluable as they give students a break and at the same time allow them to practice language skills. Games are highly motivating since they are amusing and challenging. They also encourage and increase cooperation. Therefore, a teacher is highly suggested to use games in the EFL class. The teacher will choose interesting and enjoyable games according to the demand of the students. A game must be more than just fun. It should involve friendly competition. It should keep all the students involved and interested. Lee Su Kim says that there are many advantages of using games in the classroom:

1. Games are a welcome break from the usual routine of the language class.

2. They help students to make and sustain the effort of learning.

3. Games provide language practice in the various skills- listening, speaking, reading and writing.

4. They encourage students to interact and communicate.

5. They create a meaningful context for language use.

Understanding students' learning style:

In a class there are students of different calibre. Their learning styles are also different. A teacher has to know how effective he can be in the classroom . Michelle De Cou-Landberg says that there are three types of learners- visual, auditory, and kinaesthetic. Keeping all these learners in mind, a good teacher can adopt the following steps to teach them. 
Visual learners:

They learn better by visual means. Blackboard, realia, pictures, flash cards, and maps-all of these have great potential for these learners. Although the list of possible uses for visual aids is almost endless, the following techniques suggested by Julia M. Dobson, have proved effective for conversation and writing practice.

\section{Blackboards}

1. Write new words, phrases or sentences on the blackboard and discuss these items with your students.

2. Make simple drawings on the board and use the elements for making story and topics for discussion in general.

3. Wtite one or two informative sentences on the board and have students ask you questions based on these sentences. For instance, you might write, 'I watched a football match between Bercelona and Manchester United last night”. Students may make a large number of questions from this short sentence. One day when I wrote this sentence in the board, my students asked me the following questions.

1. Do you like football?

2. Do you watch football-match?

3. Who is your favourite football player?

4. Which club do you support?

5. Do you play football in Bangladesh? 
6. Will you play football with us?

I also asked them a lot of questions about sports and games. Frequently they participated with me. What I noticed in the class is all the students are interested in sports and games. I also took the opportunity. Enery now and then I select some sports related topics for discussion and writing.

Realia:

One successful teacher can take a large bag containing different objects such as orange, comb, coins, tooth brush, paste, marker, tea-cup, knife, T-shirt etc in the class. He empties the contents on the table and then, holding up one of the items, he says, "I want each person to make a statement about this object." Again he can pick up two objects and say,"please compare these." The students enjoy talking about the objects,especially because he brings different ones in each session.

Pictures:

Visual learners always get interest in picture description. A teacher can take pictures from books, magazines, and newspapers. He can draw some pictures in the board. Students also can do it. Obviously the pictures should be well known by the students and they should have background knowledge about the pictures. Whatever the pictures are, they can serve an excellent conversation starters. Here are some ways to use pictures in the classroom:

1. Ask students to describe in detail what they see in a given picture. They should enumerate objects and persons. Then you can ask," What do you think is happening?" or "What are they doing?" leading students into making comments based on inference. 
2. Show two pictures that have many likenesses and ask the students to comment on the likenesses. You can also use this technique with two pictures that have several differences, in which case the students discuss the differences.

3. Allow the students to inspect a picture of a person. Then they should describe him fullyhis age, phisical features, expression, and even such things as freckles or a dimple. In a variation of this exercise, each student can write a description of the person and then class members can discuss their individual descriptions.

4. Show a picture of a person and have a student create a story about the person.

5. Have each student bring pictures from a current publication that tell a story. Then class members should construct appropriate stories around the pictures.

\section{Flash Cards:}

If you have a set of flash cards that show a figure or figures performing different activities such as sleeping, getting up, eating a meal, reading the newspaper, driving, working in an office, and so on, you can have a student put the flash cards into a logical sequence and then tell a story based on the sequence.

Maps:

1. Have students examine and comment on a global map or a map of their own country.

2. After acquainting everyone with locations of major cities, provinces, mountains, rivers, and so on, ask questions about these elements. For example, Where is Dammam? Where is the rocky mountains? Is there any island in Saudi Arabia? Is Jazan in the southwestern part of Saudi Arabia? 
Auditory learners:

They learn well by hearing things, for example lectures or tapes. They want to get oral instructions from their teachers. Sometimes they really like to record the lecture and they hear it at home for better understanding. For these learners a teacher can do the following things:

1. Read the lesson aloud in the class.

2. Use tape recorder or computer or multi-media projector.

3. Play some interesting story.

4. Play songs which the students like most.

5. Give the students some exercises related to listening skill.

Kinaesthetic learners:

They learn best by active participation in the class. A teacher should give them opportunity to involve in different activities physically. He can arrange debate in the class. He can invite the students to participate in different games. Sometimes he can take them out of the class and make them play football or basketball. He can arrange picnic. He can ask them to write or tell something about the picnic.

Teachers are advised to use the role-play activity for this type of learners to help the less motivated learners take part in the lesson. Besides, certain tasks in the students' book are followed by a role play- activity where it becomes a necessity to undergo such an activity. For instance we can state: the hide and guessing game, dramatizing an interview of customer and shop assistant, doctor and patient conversation, etc. 
Pair work or Group work:

One of the successful ways, if the teacher is resourseful and skillful enough to motivate his or her students to participate in the lesson is to use pair work or group work appropriately.

Language is best learnt through the close collaboration and communication among students. This type of collaboration results in benefits for all or both learners. In fact, learners can help each other while working on different types of tasks such as writing dialogues, interviews, drawing pictures and making comments about them, play roles etc.

Researches on Second Language Acquisition have shown that learners have differences in mastering skills. While one student is good in expressing ideas verbally, another can be good in drawing. A third other student can be good at role play and imitation. Besides, some students find it less stressful, if not much comfortable to learn certain rules or useses of language from their comrades than from their teacher. Finally, communicative language teaching requires a sense of community and environment of trust and mutual confidence which pair work or group work can provide.

\section{The Error Correction:}

It is always asked whether a teacher should correct all students' errors, whenever they occur. The reasonable answer is that if a teacher stop at every single error and treat it with no room for errors to take place, this will lead to a gap of communication and students will be too much afraid of making mistakes. Hence, due to being too much obsessed with making errors, students will be too much reluctant to participate.

Thus, teachers should be aware of when to correct errors and how to do that without any hurt and 
humiliation. In a learner- centered classroom, it should be better to correct errors, which students make unconsciously, whenever there is a gap of communication. Concerning the ways of how to correct errors, there are several techniques which the teacher should choose from them according to the type of the error. Among these ways of corrections we can state: self correction, peer correction and teacher correction.

Using the L1 in the EFL classroom:

There are a lot of controversies about the use of students' mother tongue in the class. The main argument against the use of the L1 in language teaching is that students will become dependent on it, and not even try to understand meaning from the context and explanation or express what they want to say within their limited command of the target language. But we have seen that there are some cases when a teacher can use the students' mother tongue such as:

1. When there is a gap of communication or total misunderstanding.

2. Sometimes, it can prevent time being wasted on fruitless explanations and instructions.

3. If a teacher does not know the students' mother tongue, he can take a good student to explain. In this way all the students understand very easily. A feeling of satisfaciton grows in them. And at the same time, the teacher can get satisfaction when he realizes that the students are happy with him.

\section{Conclusion:}

Generally, we all know that there are a lot of classroom strategies to teach English as a Foreign Language. But we can not implement them in the context of all the countries and all social www.ijellh.com 
economic backgrounds. Therefore, here in this article we have tried to focus on those strategies which a teacher can apply effectively to motivate the students of higher class societies. At the same time, we have tried to emphasis on the ceaseless experiment of a teacher in the class to find out his own innovative and effective strategies to motivate the students. Teaching English will be effective only when the students are motivated and aspired to learn it. Therefore, language teaching should take account of a variety of factors that are likely to promote success. As a result, foreign langeage learning has a significant impact on the social being of the learners since it involves the adoption of new social and cultural behaviours and ways of thinking. 


\section{References}

Dornyei, Z. 2001. Teaching and Researching Motivation. England: Pearson Education Limited.

Good, T.L. and Brophy, J. E.1994. Looking in Classrooms. $6^{\text {th }}$ edition. New York: Harper Collins.

MacIntyre, P. D. 1999. Language anxiety: A review of research for language Teachers.

Dimitrois Thanasaulas. 2002. Motivation and Motivating in the foreign language classroom.

Rosie Tanner and Catherine Green. 2004. Tasks for Teacher Education. Pearson Education Limited.

Mohammad Ali Alkhuli. 1980. Teaching English as a Foreign Language. P-17.

Alexenoamen. 2009-11:54. Ways of Motivating EFL students in the class. British Council.

Mathew Waller. First Day of Class. March 14, 2005. Los Angeles Business Journal.

Barbara Gross Davis. Tools for Teaching. September1, 1999. University of California. Berkely.

Aydan Ersoz. Six Games for the EFL classroom. The Internet TESL journal. Vol-6. No-6, june2000.

Lee Su Kim. Creative Games for the Language class. Forum. Vol-33, no-1. January-March, page- 35 .

Julia M Dobson. Effective Techniques for English Conversation Groups. Office of English Language Programs. US State Department.2005. 